\title{
Diferenças entre dialogismo e polifonia
}

\section{Differences between dialogism and polyphony}

\author{
Lucas Vinício de Carvalho Maciel \\ UERN $^{*}$ \\ lucasvcmaciel@yahoo.com.br
}

Resumo: É por vezes polêmico o uso que se tem feito dos termos "dialogismo" e "polifonia" em estudos que se valem das discussões bakhtinianas. Ao lado de pesquisadores que tomam os vocábulos praticamente como sinônimos, outros estudiosos condenam veemente o emprego de uma expressão por outra. Dada essa conjuntura, pretendese, no escopo deste artigo, indicar alguns pontos a serem considerados quando se fizer necessário distinguir dialogismo e polifonia. São esses pontos: a amplitude do diálogo; as relações entre microdiálogo, diálogo composicionalmente expresso e grande diálogo; a questão do diálogo inconcluso (BAKHTIN, 1929[1963]). Com base nessa discussão, esboça-se um conciso painel dos modos pelos quais os conceitos de polifonia e dialogismo vêm sendo abordados em pesquisas atuais, discutindo as possibilidades e os limites dessas diferentes assimilações. $\mathrm{O}$ intuito não é criticar quaisquer usos dos termos ou apropriações dos conceitos, mas reforçar que a polifonia não se diferencia do dialogismo simplesmente porque, à diferença deste, conjugaria várias vozes ou vozes polemicamente orientadas.

\footnotetext{
*As reflexões expostas neste texto são caudatárias da pesquisa desenvolvida com apoio financeiro do CNPq (Processo 141428 / 2011-2).
} 
Palavras-chave: polifonia; dialogismo; relações dialógicas; Círculo de Bakhtin; romance polifônico.

Abstract: There are controversies regarding the use of the terms "dialogism" and "polyphony". Some researchers practically turn the two words into synonyms, while another part of the academy condemns vehemently the use of these terms as if they had the same meaning. Given this situation, some points that can be taken into consideration when there is a need to point out the difference between dialogism and polyphony are indicated along this article. The dialogue amplitudes, the relations between microdialogue, compositionally expressed dialogue and great dialogue, and the inconclusive dialogue (BAKHTIN, 1929 [1963]) are the points we aim to work with. From this discussion, a brief framework is outlined to present the ways through which the concepts of polyphony and dialogism have been approached in current researches, discussing the possibilities and the limits of these different assimilations. It is not our intention to criticize any of the uses or appropriations of these concepts, but to reinforce that polyphony's characteristic of putting several voices or polemically oriented voices together is not the only thing that differentiates it from dialogism. Keywords: polyphony; dialogism; dialogic relations; Bakhtin Circle; polyphonic novel.

Recebido em 08 de abril de 2015. Aprovado em 17 de agosto de 2015.

\section{Introdução}

Os termos "dialogismo" e "polifonia", assim como seus adjetivos correlatos "dialógico" e "polifônico", encontram-se atualmente dispersos por muitos trabalhos acadêmicos da área de Letras, tanto em estudos linguísticos quanto literários. Aliás, esses vocábulos podem até mesmo ser encontrados em materiais e práticas didáticas.

Esse cenário é resultado da influência que certas reflexões do Círculo de Bakhtin vêm alcançando no espaço acadêmico brasileiro 
e, no caso da difusão para o contexto escolar, em muito contribuíram os Parâmetros Curriculares Nacionais (PCN) de Língua Portuguesa Terceiro e Quarto Ciclos do Ensino Fundamental (BRASIL, 1998), que destacam a importância dos gêneros textuais, dos elementos constitutivos do enunciado e do aspecto dialógico da linguagem. Todos esses aspectos colocados pelos PNC estão, direta ou indiretamente, baseados em reflexões do Círculo de Bakhtin, com destaque especial para os pontos expressos por Bakhtin no ensaio Os gêneros do discurso (BAKHTIN, [1952-1953]).

Dada essa disseminação dos conceitos bakhtinianos, é comum encontrar trabalhos que indistintamente tomam os termos "dialogismo" e "polifonia" como sinônimos, bem como estudiosos que criticam veementemente o uso de um vocábulo por outro.

No âmbito dessa polêmica, pretende-se, neste artigo, apontar algumas diferenças entre dialogismo e polifonia, não a fim de criticar os usos que se têm feito dos termos, mas procurando fomentar o debate ao indicar alguns pontos a serem considerados quando se julga necessário distinguir polifonia de dialogismo. Apresentando um breve painel de tendências recorrentes em pesquisas quando se considera essa (in) distinção, serão apontados as possibilidades e os limites das apropriações que se têm feito das discussões bakhtinianas.

\section{Considerações iniciais sobre dialogismo e polifonia}

Para iniciar a discussão acerca das possíveis diferenças entre dialogismo e polifonia, vale lembrar que, embora o termo "dialogismo" seja corriqueiro em estudos de viés bakhtiniano, a expressão mais presente nos textos de Bakhtin é "relações dialógicas". Em Problema da poética de Dostoiévski (BAKHTIN, 1929 [1963]), texto central para se distinguir dialogismo de polifonia, o termo "dialogismo" ocorre pouquíssimas vezes, sendo bem mais frequente o uso da expressão "relações dialógicas".

Ainda assim, nas apropriações que se tem feito dos textos bakhtinianos, é bastante frequente o uso do termo "dialogismo", comumente conceituado como uma relação entre diferentes textos. Contudo, na acepção bakhtiniana, o dialogismo não é apenas a referência de um texto a outro, mas as relações (dialógicas) que se dão entre uma voz ou outra, estejam essas vozes expressas em um mesmo texto ou 
em diferentes textos, estejam essas vozes nos diálogos face a face do cotidiano ou em amplos diálogos que se estabelecem, marcadas ou veladamente, entre vozes e ideias que interagem, por meio de sujeitos que as enunciam, no fio da história.

Também o uso da palavra "polifonia" inspira algum cuidado, especialmente porque é pouco frequente nos textos bakhtinianos, estando de fato mais efetivamente presente em Problemas da poética de Dostoiévski. Como bem nota Emerson (1997), a "polifonia [...] acabou sendo ocasionalmente confundida com dialogismo, heteroglossia, zonas de voz, análise cronotópica - slogans [...] que Bakhtin só veio a conceber mais tarde $[\ldots] "$ ".

Aliás, em Problemas da poética de Dostoiévski, polifonia é usada como uma metáfora para se designar um novo modo de conceber e estruturar o romance. Esse novo modo seria visível, segundo Bakhtin, em algumas obras de Dostoiévski. É por isso que, na verdade, raramente é empregada por Bakhtin a palavra "polifonia", já que em geral é na expressão "romance polifônico" que a ideia de polifonia aparece. Nesse caso, a concepção de polifonia está associada ao gênero romanesco, vinculada às especificidades desse gênero narrativo da prosa literária.

Assim, se "dialogismo" pode ser entendido como uma relação mais genérica entre vozes que se relacionam, "polifonia", a princípio, estaria ligada ao gênero romanesco. Por isso, para se pensar a respeito de alguns pontos pelos quais se pode diferenciar dialogismo de polifonia, é interessante observar que o próprio Bakhtin, em seu estudo da prosa dostoievskiana, estabelece critérios que o permitem classificar algumas obras de Dostoiévski como polifônicas.

\section{Alguns critérios para distinguir dialogismo de polifonia}

Embora não de forma sistemática, Bakhtin apresenta em Problemas da poética de Dostoiévski alguns pontos interessantes para se refletir acerca da distinção entre polifonia e dialogismo: (i) a amplitude em que são os diálogos entre personagens e narrador; (ii) a integração entre diálogo interior (ou microdiálogo), diálogo composicionalmente expresso e grande diálogo; e (iii) a questão do diálogo inconcluso.

Ao abordar cada um desses temas, será possível apontar algumas diferenças entre dialogismo e polifonia. 


\section{A amplitude do diálogo}

Bakhtin entende haver um desenvolvimento da "ciência do diálogo" (BAKHTIN, 1929[1963], p. 300) em Dostoiévski, uma ciência que se apresentaria progressivamente mais complexa no curso das publicações do romancista russo.

Em Gente Pobre (1846), por exemplo, primeira obra de Dostoiévski, o "mundo das personagens" seria "restrito e estas ainda não" seriam "ideólogas" (BAKHTIN, 1929[1963], p. 238). Isso porque, nessa novela inaugural do escritor, as personagens dialogam apenas com aqueles que lhes estão próximos, sem conseguir ainda diálogos mais amplos.

Gente Pobre é basicamente estruturada nos diálogos, por meio de cartas, entre Makar Diévuchkin e Várienka. As falas dessas personagens se restringem a problemas imediatamente relacionados à vida delas. Mesmo que essas personagens sofram as influências de uma conjuntura cultural e política ampla, questões mais abrangentes ainda não têm significado considerável para elas. Não se vê em Gente Pobre discussões de cunho filosófico mais abrangente, debates acerca dos rumos políticos da Rússia de então, reflexões complexas acerca da natureza do homem. Essas questões talvez não apareçam nessa novela inaugural de Dostoiévski porque as personagens são pessoas humildes, sem conhecimento acerca de questões mais complexas. A própria condição social das personagens, que beira à miséria, faz com que suas questões sejam as do dia a dia, aquelas do aqui e agora, em uma vida que se vive cada dia de uma vez, inclusive em termos da manutenção financeira.

Além disso, talvez o gênero novela ainda não fosse tão adequado quanto o romance para uma composição em que houvesse espaço (composicional) suficiente para se discutir a fundo e de várias perspectivas questões mais densas. Pode ser também que o jovem escritor ainda não tivesse maturidade como autor para compor uma obra em que questões existenciais, filosóficas e políticas ganhassem tamanha dimensão.

Enfim, fato é que os diálogos dos primeiros heróis de Dostoiévski ainda são bastante restritos ao círculo imediato de suas vidas. Na passagem a seguir, transcrita por Bakhtin (1929[1963], p. 236), Makar descreve por meio de suas palavras, de sua autoenunciação, o quarto que aluga para habitar.

"Eu moro na cozinha, ou seria bem mais correto dizer assim: aqui ao lado da cozinha (mas, preciso lhe dizer, a nossa cozinha é limpa, clara, muito 
boa) existe um quartinho, pequeno, um cantinho modesto... isto é, para dizer melhor ainda, a cozinha é grande, tem três janelas, de sorte que ao longo da parede transversal há um tabique, de maneira que isso resulta como que em mais um cômodo, um quarto extranumerário; tudo amplo, confortável, tem até janela, e tudo - numa palavra, tudo confortável. Pois bem, é esse o meu cantinho. Bem, mas não vá você pensar, minha cara, que nisso aqui exista alguma outra coisa, um sentido misterioso; que, vamos, se trate de uma cozinha! - quer dizer, eu moro mesmo nesse quarto, atrás do tabique, mas isso não é nada; vivo cá em meu canto, isolado de todos, modestamente, às ocultas. Pus em meu quarto uma cama, uma mesa, uma cômoda, um par de cadeiras, pendurei um ícone na parede. É verdade, existem quartos melhores - talvez até bem melhores, mas o essencial é o conforto; pois eu faço tudo isso pelo conforto, e não vá você pensar que seja por outra coisa."1

Logo após a transcrição desse trecho de Gente Pobre, Bakhtin comenta (1929[1963], p. 236):

“Quase após cada palavra [Makar] Diévuchkin lança uma mirada para sua
interlocutora ausente, teme que ela o imagine queixoso, procura destruir
a impressão provocada pela notícia de que ele vive na cozinha, não quer
lhe causar desgosto, etc.”, de tal modo que "as palavras de Diévuchkin
sobre si mesmo" são determinadas pela “palavra possível do destinatário,
no caso Várienka Dobrossiélova" (BAKHTIN, 1929[1963], p. 236).

A enunciação de Diévuchkin, suas palavras voltam-se a Várienka, moça que pertence ao seu "mundo restrito".

Para Bakhtin, esse tipo de interlocução mostra personagens que não seriam ideólogas, porque seus discursos não seriam "sobre o mundo", mas apenas "sobre si mesmo[as] e sobre seu ambiente imediato" (BAKHTIN, 1929[1963], p. 87).

De todo modo, o alargamento desses diálogos ocorre já em uma das primeiras obras dostoievskianas, A senhoria. Publicada em 1847, A senhoria é a quarta obra do autor, precedida apenas por Gente Pobre (1846), O duplo (1846) e O senhor Prokhártchin (1847).

Segundo Bianchi (2006, p. 117, grifo nosso):

${ }^{1} \mathrm{O}$ trecho transcrito de Gente Pobre segue a tradução presente em Problemas da poética de Dostoiévski. As aspas são mantidas, conforme no texto de Bakhtin. 
Esta [A senhoria] é a primeira obra de Dostoiévski em que aparece uma personagem intelectual, com origem numa classe social superior. Vassíli Mikháilovitch Ordínov é um jovem da capital, de origem nobre e com cultura. É o primeiro personagem do escritor que se aproxima do tipo do "herói do tempo", constituindo sua primeira tentativa de configuração de um herói da intelligentsia aristocrática. Apesar de ser um "desclassificado", no sentido de que está privado do bem-estar e dos privilégios de sua classe, o "herói" de Dostoiévski, de qualquer forma, é um homem de uma camada cultural superior.

Ordínov, protagonista de A senhoria, representa o primeiro ideólogo dostoievskiano, um sujeito que está imerso em seus problemas cotidianos, mas não deixa de pensar a respeito de temas de caráter mais amplo, de questões que vão além de sua realidade individual imediata. Por sua "cultura superior", ele pode dialogar com vozes que não estejam diretamente presentes em seu círculo imediato de vida.

Todavia o primeiro ideólogo citado por Bakhtin em Problemas da poética de Dostoiévski é a personagem central de Memórias do subsolo. Esse protagonista, o "paradoxalista", já seria um "ideólogo", pois debate com vozes sociais mais abrangentes, as quais permeiam o meio social em que vive.

De acordo com Bakhtin (1929[1963], p. 273): "A polêmica com o outro a respeito de si mesmo é complexificada em Memórias do subsolo pela polêmica com o outro sobre o mundo e a sociedade. Diferentemente de Diévuchkin e Goliádkin, ${ }^{2}$ o herói do subsolo é um ideólogo". Isso porque em Memórias do subsolo já aparecem vozes que vão além do mundo restrito da personagem, vozes que manifestam certos valores sociais mais amplos. Se as reflexões de Diévuchkin e Goliádkin estão voltadas a seus contextos imediatos de vida, o "homem do subsolo" já discute assuntos mais abrangentes e se dirige a um outro qualquer, um "'outro' como tal, independente [sic] de quem seja" (BAKHTIN, 1929[1963], p. 309). A autoenunciação do "homem do subsolo" é uma "confissão" não dirigida especificamente a alguém, mas ao mundo. Aliás, o "homem do subsolo", como nota Bakhtin, não fala "sobre o universo, mas com o universo" (Ibid., p. 273). Daí porque seu discurso, um discurso "apelo" (Ibid., p. 274), nas palavras de Bakhtin, dirija-se a qualquer um, a um outro qualquer.

\footnotetext{
${ }^{2}$ Personagens principais, respectivamente, das novelas Gente Pobre e $O$ duplo.
} 
Assim, enquanto ideólogo, o "homem do subsolo" não está preso à sua realidade imediata, conseguindo discutir com vozes mais amplas, até aquelas que não possuem um representante físico imediatamente presente, mas que podem, contudo, ser reconhecidas pela personagem que com elas dialoga.

A importância dos ideólogos, presentes em Memórias do subsolo e já desde A senhoria, revela-se porque, nesse caso, os diálogos são mais amplos, abarcando vozes e ideias disseminadas na época. Trata-se de um passo importante no desenvolvimento da "ciência do diálogo" dostoievskiana até se chegar a romances como Crime e castigo e O idiota, que trazem os intrincados jogos dialógicos a que Bakhtin denominará "polifonia". Polifonia essa cujo exemplo mais elaborado se encontra na última obra de Dostoiévski, Os irmãos Karamázov.

Bakhtin estabelece, assim, embora não de modo explícito, que há obras nas quais se encontram relações dialógicas - como Gente Pobre e $O$ duplo - e outras em que essas relações são de tal maneira desenvolvidas que é possível distingui-las como polifônicas - como os romances Crime e castigo, $O$ idiota e Os irmãos Karamázov, por exemplo. A amplitude e a complexidade das relações dialógicas ajudam a diferenciar os romances polifônicos das novelas e romances dialógicos.

No desenvolvimento da ciência do diálogo dostoievskiana, inicia-se com as personagens restritas a seus interlocutores imediatos, passa-se depois a personagens que assimilam temas sociais mais amplos até se chegar a romances cujos arranjos dialógicos entre as vozes de várias personagens são a tal ponto aprofundados que se chegaria à polifonia. Ou seja, um dos critérios para se distinguir polifonia de dialogismo é a amplitude do diálogo. Somente com ideólogos e considerando-se vozes mais amplas (e pensamentos mais abstratos) se supera o diálogo imediato. Se o dialogismo já se faz presente na interação entre quaisquer vozes, a polifonia depende da amplitude das ideias que se discute.

\section{A interação entre microdiálogo, diálogo composicionalmente expresso e grande diálogo}

Além da amplitude do diálogo, outro aspecto a ser considerado quando se fala em romance polifônico é haver interação entre microdiálogo, diálogo composicionalmente expresso e grande diálogo. 
De acordo com Bakhtin (1929 [1963], p. 310):

[...] o diálogo exterior composicionalmente expresso é inseparável do diálogo interior, ou seja, do microdiálogo, e em certo sentido neste se baseia. E ambos são igualmente inseparáveis do grande diálogo do romance em seu todo, que os engloba. Os romances de Dostoiévski são totalmente dialógicos.

O diálogo interior ou microdiálogo é o diálogo que se estabelece no interior da consciência de uma personagem. Esse diálogo interior é alimentado por vozes com as quais a personagem entrou em contato, geralmente por meio de diálogos exteriores, em conversas com outros sujeitos. Nas representações literárias, essas interações face a face são denominadas, por Bakhtin, diálogos composicionalmente expressos. Há, desse modo, um jogo entre os diálogos interiores e exteriores, que se alimentam reciprocamente, pois uma ideia verbalizada em diálogo exterior pode adentrar a consciência do sujeito, seu diálogo interior, e, em momento posterior, ser (re)exteriorizada, convocada a participar dos diálogos exteriores com outros partícipes da interação.

No caso dos romances polifônicos, essa intricada relação entre diálogos interiores e exteriores é trabalhada extensamente e em profundidade, sendo as vozes ditas e reditas várias vezes, a cada momento recebendo novas nuanças, num complexo jogo de reelaboração das ideias de que resulta o grande diálogo.

Nesse sentido, Gente Pobre e $O$ duplo, por exemplo, não seriam obras polifônicas, pois se há microdiálogos e diálogos composicionalmente expressos, não se chega a uma profunda discussão de ideias, o que demandaria que as vozes das personagens fossem extensamente debatidas por outras personagens, por meio das complexas interações que caracterizam o grande diálogo. Isso porque, além das relações entre microdiálogo e diálogo composicionalmente expresso, é preciso haver a "transferência das palavras de uma boca para outra, quando elas conservam o mesmo conteúdo, mas mudam o tom e o seu último sentido" (BAKHTIN, 1929[1963], p. 249). Ou seja, é preciso que as vozes das personagens se confrontem, que uma possa ouvir sua voz na boca do outra, mas com diferente sentido, com acento diverso.

Um dos exemplos empregados por Bakhtin para ilustrar esse procedimento são as complexas e profundas relações que se estabelecem 
entre as vozes das personagens Ivan, Aliócha e Smierdiakóv em Os irmãos Karamázov. Ivan se sente culpado pelo assassinato do pai, mas seu irmão Aliócha refuta veementemente essa (auto)acusação ao dizer "não foste tu". Ainda assim, Ivan continua se martirizando, até mesmo porque o real assassino, Smierdiakóv, diz ter cometido o crime afiançado nos ensinamentos de Ivan, que supostamente lhe houvera ensinado que "tudo é permitido" (DOSTOIÉVSKI, 1881, p. 816).

No emaranhado jogo de relações dialógicas estabelecidas entre essas vozes delineia-se a "polifonia de princípio" de que fala Bakhtin (1929[1963], p. 310), pois há a passagem de uma voz por várias e diferentes bocas.

A título de ilustração, segue trecho de Os irmãos Karamázov, reproduzido por Bakhtin (1929[1963], p. 296-297, grifo do autor), em que os irmãos Aliócha e Ivan conversam sobre o possível assassino do pai deles:

- Só uma coisa eu sei - pronunciou Aliócha do mesmo modo quase sussurrando. - Quem matou nosso pai não foste tu.

- "Não foste tu"! Que não foste tu é esse? - Ivan estava petrificado.

- Não foste tu que matou nosso pai, não foste tu! - repetiu Aliócha com firmeza. Fez-se uma pausa de meio minuto.

- Ora, eu mesmo sei que não fui eu, está delirando? - pronunciou Ivan com um riso pálido e contraído. Tinha o olhar como que cravado em Aliócha. Mais uma vez estavam parados diante do lampião.

- Não, Ivan, tu mesmo disseste várias vezes a ti mesmo que era o assassino.

- Quando foi que eu disse? (...) Eu estava em Moscou... Quando foi que eu disse? - balbuciou Ivan totalmente desconcertado.

- Tu disseste isto a ti mesmo muitas vezes quando ficaste só nesses dois terríveis meses - continuou Aliócha com voz baixa e nítida. Mas já falava como tomado de extrema excitação, como movido não por sua vontade, obedecendo a alguma ordem indefinida. - Tu te acusavas e confessavas a ti mesmo que o assassino não era outro senão tu. Mas quem matou não foste tu, estás enganado, não és tu o assassino, ouve-me, não és tu! Foi Deus quem me enviou para te dizer isso.

A voz interior de Ivan que o condena pelo assassinato de seu pai é refutada por Aliócha, que afirma categoricamente "não foste tu". Observa-se, assim, a passagem de uma mesma afirmação "por diferentes 
vozes que se opõem umas às outras" (BAKHTIN, 1929[1963], p. 298), na medida que a colocação de Aliócha rebate a acusação que Ivan faz a si próprio. A voz do Ivan é retomada por Aliócha, que modifica sua entonação. Se na voz de Ivan há a acusação, na de Aliócha há o perdão.

Esse diálogo, porém, não estará encerrado, pois, mesmo sob o matiz da absolvição de Aliócha, Ivan ainda continua a se martirizar, até mesmo porque em seu diálogo interno ecoa também a voz de Smierdiakóv, que o acusa, se não do assassinato, pelo menos, da cumplicidade e, até mesmo, de influência e instigação para tal ato.

Smierdiakóv, o assassino, em sua última conversa com Ivan, retoma algumas das palavras ditas por este em outras oportunidades:

Antes eu alimentava a ideia de começar uma nova vida com esse dinheiro, em Moscou ou, melhor ainda, no exterior, eu acalentava esse sonho, ainda mais porque "tudo é permitido". Isso o senhor me ensinou de verdade, porque naquela época o senhor me dizia muitas coisas como essa: pois se Deus definitivamente não existe, então não existe nenhuma virtude, e neste caso ela é totalmente desnecessária. Isso o senhor realmente me disse. E foi assim que julguei (DOSTOIÉVSKI, 1881, p. 816).

Vê-se que Smierdiakóv acusa Ivan de tê-lo feito acreditar que "tudo é permitido", que "Deus definitivamente não existe, então não existe virtude nenhuma". Ao ouvir da boca de Ivan que tudo é permitido, Smierdiakóv acredita que aquele o incita ao crime: o crime seria permito, pois tudo é permitido, não há virtude. Segundo Smierdiakóv, a justificativa para seu crime foram os "ensinamentos" de Ivan e, por isso, este também se sente culpado pelo assassinato do pai.

Esboça-se, assim, um emaranhado jogo de relações dialógicas: há relações entre microdiálogo, diálogo composicionalmente expresso e grande diálogo; há a passagem de uma voz por várias e diferentes bocas. As palavras que ecoam no microdiálogo de Ivan, que disse a si "mesmo muitas vezes" quando ficara só que era o assassino, também aparecem nos diálogos composicionalmente expressos da personagem com Aliócha e com Smierdiakóv, quando se discute se (não) "foste tu".

A propósito, se o crime nasce das diferentes interpretações de ser "tudo permitido", esta questão está relacionada a outro debate fundamental para as personagens: a existência ou não de Deus. Veja-se que a justificativa de ser tudo permitido está associada à inexistência de 
Deus. Essa questão passa pela voz das personagens citadas - Ivan, Aliócha e Smierdiakóv -, mas também é debatida por outras personagens e em outras conjunturas dialógicas, por exemplo, Fiódor (o pai que depois seria assassinado), Ivan e Aliócha discutem acerca da existência de Deus.

A seguir, transcreve-se trecho dessa conversa, inserindo entre colchetes o nome das personagens antes das suas falas para facilitar a compreensão:

[Fiódor] - Bem, sendo assim, quer dizer que eu sou um russo, e que tenho um traço russo, e que a ti também, filósofo ${ }^{3}$, posso te apanhar nesse mesmo traço. Se quiseres eu te apanho. Podemos apostar que amanhã mesmo te apanho. Mas, mesmo assim, dize: Deus existe ou não? Só que fala a sério! Agora precisas me dizer a sério.

[Ivan] - Não, Deus não existe.

[Fiódor] - Alióchka, ${ }^{4}$ Deus existe?

[Aliócha]-Deus existe.

[Fiódor] - Ivan, a imortalidade existe? Vamos, alguma que seja, mesmo a mais pequena, a mais ínfima?

[Ivan] - Também não existe a imortalidade.

[Fiódor] - Nenhuma?

[Ivan]-Nenhuma.

(DOSTOIÉVSKI, 1881, p. 196).

Na versão utilizada, essa cena aparece na página 196 do volume I da obra Os irmãos Karamázov. Já a passagem anteriormente citada, em que Smierdiakóv confronta Ivan, está na página 816 do volume II da obra. Mais de 600 páginas separam esses diálogos, um espaço composicional suficiente para que a questão da existência de Deus passe por "muitas e diferentes vozes" (BAKHTIN, 1929[1963], p. 249).

Isso parece conduzir à hipótese de que o "grande diálogo", conforme entendido por Bakhtin, é exclusivo do romance ou, pelo menos, estaria restrito a certos gêneros narrativos mais extensos. Gêneros relativamente curtos dificilmente apresentariam várias personagens e, mais importante do

\footnotetext{
${ }^{3}$ Fiódor se refere ironicamente ao seu filho Ivan como "filósofo", por seus posicionamentos céticos.

${ }^{4}$ Alióchka é Aliócha. A grafia dos nomes em russo varia de acordo com a situação e a formalidade
} 
que isso, dificilmente haveria espaço composicional na narrativa para que as vozes das personagens fossem retomadas e discutidas por outras personagens, amadurecidas ou testadas em microdiálogos para, depois, novamente voltarem a diálogos composicionalmente expressos, em um complexo jogo de interações discursivas. O grande diálogo está em estrita ligação com o gênero romanesco. Talvez seja possível em outros gêneros, mas não em todos.

\section{O diálogo inconcluso}

A respeito do romance polifônico é importante também frisar a questão do "diálogo incluso". 5 Seguindo ainda com o exemplo anterior, no que se refere à questão de ser "tudo permitido", observa-se que o debate não terminará, pois Ivan cai em uma espécie de loucura ou delírio, sem conseguir se reconhecer culpado ou se assumir inocente. Assim, permanece inconclusa a questão de ser "tudo permitido", questão esta relacionada à existência ou não de Deus.

Isso indica que, além da passagem das ideias por muitas e diferentes vozes, aspecto importante da polifonia é a "infinitude potencial do diálogo", a "inconclusibilidade do diálogo" (BAKHTIN, 1929[1963], p. 293). É justamente falando dessa inconclusibilidade em certos diálogos da obra dostoievskiana que Bakhtin lança a afirmação tão repetida em vários estudos (literários ou não): "Ser significa comunicar-se pelo diálogo. Quando termina o diálogo, tudo termina. Daí o diálogo, em essência, não poder nem dever terminar". (BAKHTIN, 1929[1963], p. 293).

Conforme Bakhtin, nos "romances de Dostoiévski" está colocada "a infinitude potencial do diálogo". Tanto assim que muitas vezes o texto termina, mas o diálogo não. Para Bakhtin, um exemplo evidente de diálogo inconcluso seria o encerramento de Memórias do subsolo, que formalmente exige "fazer ponto final aqui mesmo" (DOSTOIÉVSKI, 1864, p. 147), embora se informe ao leitor que o homem do subsolo "não se conteve" e continuou em seus diálogos. ${ }^{6}$

\footnotetext{
${ }^{5}$ À semelhança deste artigo, Marcuzzo (2008, p. 3) se propõe "definir e distinguir" "os conceitos de dialogismo e polifonia”, destacando a questão do diálogo inconcluso. Suas conclusões, porém, divergem das aqui apresentadas.

${ }^{6}$ Memórias do subsolo, porém, não seria um romance polifônico, pois as ideias não passam por "muitas e diferentes vozes" (BAKHTIN, 1929[1963], p. 249), permanecendo especialmente no âmbito do diálogo interior do "paradoxalista".
} 
Esse aspecto é importante, pois como nota Bakhtin, em Dostoiévski não se tem algo dialético, o confronto de vozes que chega a uma síntese, uma síntese dialética. A síntese pressupõe um consenso, uma palavra vencedora, mas na polifonia dostoievskiana não há vencedores nem vencidos, a guerra (o diálogo) ainda não terminou.

Segundo Bakhtin (1929[1963], p. 28-29), nos romances (polifônicos) de Dostoiévski não "ocorre [...] uma oposição dialeticamente superada entre muitas consciências que não se fundem em unidade do espírito em processo de formação [...]". Isso porque as relações entre as personagens não "se podem reduzir às relações de tese, antítese e síntese", "os romances dostoievskianos não representam nem expressam a formação dialética do espírito" (BAKHTIN, 1929[1963], p. 29).

A dialética prevê a oposição de perspectivas, de vozes (para usar um termo bakhtiniano), mas também prevê um fechamento, uma síntese, uma conclusão que não está presente nos romances dostoievskianos em que o autor se recusa a dar uma palavra final. Assim, polifonia não pode ser entendida com um processo dialético ou, pelo menos, não como um processo dialético que chega a uma síntese.

Uma das inovações dostoievskianas é sua nova forma de romance em que nenhuma voz-ideia de autor, de narrador ou de qualquer personagem sai vitoriosa, sintetiza a verdade última.

Aliás, essa nova forma de romance implicou a necessidade um novo arranjo entre os partícipes da narrativa, uma nova relação entre autor, narrador e personagens. No romance polifônico, o autor procura se aproximar das personagens, sem impor sua voz de uma distância autoritária. Dar a palavra final comprometeria o projeto do romance polifônico em que a voz da personagem "é como se soasse ao lado da palavra do autor" (BAKHTIN, 1929[1963], p. 5, grifo do autor).

Por soar ao lado e não acima, nenhuma voz, nem mesmo a do autor, está autorizada a dar a palavra final, nenhuma voz encerra o diálogo. Esse também é um aspecto importante quando se fala de polifonia: o autor / narrador exerce sua distância em relação às personagens de um modo especial. Permanecendo "ao lado" das personagens, a voz do autor não é mais autoritária, não se impõe para dar a última palavra. Essa nova posição do autor é requisito para o não fechamento do diálogo. Segundo Bezerra (2005, p. 199): "É essa posição do autor em relação às personagens que caracteriza a polifonia no romance". 
Assim, outro aspecto importante para se pensar em polifonia é a abertura do diálogo, que não é encerrado por uma voz que, supostamente, pudesse sintetizar ou subjugar as demais. Conforme pontua Faraco (2003, p. 75, grifos do autor): "Polifonia não é, para Bakhtin, um universo de muitas vozes, mas um universo em que todas as vozes são equipolentes".

\section{Alguns usos dos termos "dialogismo" e "polifonia"}

Uma vez pontuados alguns aspectos que podem ser de interesse para se divisar diferenças entre dialogismo e polifonia, propõe-se, então, observar como têm sido abordados esses conceitos em recentes pesquisas. Ao percorrer textos acadêmicos, encontram-se pelo menos três modos de se enfrentar a controversa (in)distinção entre dialogismo e polifonia: (i) utilizam-se polifonia e dialogismo como sinônimos; (ii) distinguemse polifonia de dialogismo, mas se considera a possibilidade dos dois fenômenos ocorrerem em quaisquer textos; e (iii) distinguem-se polifonia de dialogismo, entendendo que a polifonia só se faz presente na prosa romanesca ou apenas na prosa romanesca dostoievskiana.

Comenta-se, a seguir, cada uma dessas abordagens.

\section{(i) Utilizam-se polifonia e dialogismo como sinônimos}

Essa primeira perspectiva está equivocada, pois polifonia e dialogismo são distintos, embora possam ser equivalentes em alguns aspectos. A propósito, é relevante destacar dois pontos: a) isso não significa que polifonia seja algo superior ao dialogismo, como se a polifonia fosse a execução máxima das relações dialógicas. Na polifonia está implicado um dos modos (singular) de organização das relações dialógicas; e b) é fácil constatar que inúmeros trabalhos acadêmicos utilizam polifonia e dialogismo como sinônimos. Brait (1994, p. 22), por exemplo, já afirmou que "polifonia [...] é apenas um outro termo para dialogismo".

Antes de acusar o "erro" desses trabalhos, é preciso ver se neles realmente polifonia e dialogismo se recobrem mesmo que parcialmente e, principalmente, lembrar que as discussões bakhtinianas ainda são de certo modo recentes. Daí porque a apropriação dos conceitos bakhtinianos estejam mudando. Um autor que outrora empregou polifonia como sinônimo de dialogismo, hoje talvez não o faça. 


\section{(ii) Distinguem-se polifonia de dialogismo, mas se considera a pos- sibilidade de dois fenômenos ocorrerem em quaisquer textos}

Nessa perspectiva se enquadram, possivelmente, muitas das pesquisas em curso no Brasil, as quais distinguem polifonia de dialogismo, mas consideram que a polifonia não é exclusiva de textos dostoievskianos. Para citar um exemplo, Koch (1997, p. 73), comparando intertextualidade e polifonia, considera esta um fenômeno bastante abrangente em que "incorporam-se ao texto vozes de enunciadores reais ou virtuais, que representam perspectivas, pontos de vista diversos, ou põem em jogo 'topoi' diferentes [...]". Entre os exemplos arrolados pela autora, há textos jornalísticos, provérbios e letras de música, ou seja, a polifonia se faria presente em vários gêneros do discurso e em vários autores.

Ao lado de posicionamentos como esse, é possível ainda encontrar vários outros modos pelos quais se pretende divisar polifonia e dialogismo. Há aqueles que consideram que a polifonia se distingue do dialogismo, porque, diferentemente do dialogismo, na polifonia haveria vozes conflitantes. Outros relacionam a polifonia a gêneros discursivos e até a alguns autores: assim seria possível observar a polifonia na prosa romanesca, em certos contextos comunicativos, em certos autores.

Vale, contudo, pontuar que a polifonia não se caracteriza (apenas) por conjugar vozes opostas. A polifonia não se diferencia do dialogismo porque nela se confrontariam vozes opostamente orientadas, enquanto no dialogismo isso não ocorreria. Se assim fosse, um texto acadêmico que retoma a voz do outro para confrontá-la seria um exemplo de polifonia. Como sublinha Faraco (2003, p. 66), as relações dialógicas "não apontam somente na direção das consonâncias, mas também das multissonâncias e das dissonâncias". Assim, os conflitos entre vozes não estão reservados apenas à polifonia, fazendo-se presentes também no dialogismo. Daí porque o critério da polêmica ou de vozes diversamente orientadas não possa distinguir os dois fenômenos.

A polifonia também não pode ser considerada específica de determinado(s) gênero(s) discursivo(s), sem que antes pesquisas provem essa assertiva. Julgar que a polifonia é exclusiva de certos autores também depende do desenvolvimento de mais pesquisas.

Assim, a polifonia pode ser considerada para o estudo de outros textos que não determinados romances de Dostoiévski, desde que não se esqueça de ter sido com base nesse material que Bakhtin construiu o 
conceito de polifonia. Utilizá-lo para outras análises não apenas é válido como, principalmente, produtivo. Ainda assim, é relevante não perder de vista que muitas das colocações bakhtinianas se fizeram por conta das especificidades de certa prosa romanesca de Dostoiévski, o que implica algum cuidado com o conceito de polifonia ao tratar de outros enunciados.

Nesse sentido, mesmo sem defender que o termo "polifonia" seja puritanamente salvaguardado de quaisquer flexibilizações, discorda-se da posição de Barros (1997). comenta:

Procurando distinguir polifonia de dialogismo, a pesquisadora

Em trabalho anterior (1994) sobre o assunto, distingui claramente dialogismo e polifonia, reservando o termo dialogismo para o princípio dialógico constitutivo da linguagem e de todo discurso e empregando a palavra polifonia para caracterizar um certo tipo de texto, aquele em que o dialogismo se deixa ver, aquele em que são percebidas muitas vozes, por oposição aos textos monofônicos, que escondem os diálogos que os constituem. Trocando em miúdos, pode-se dizer que o diálogo é condição da linguagem e do discurso, mas há textos polifônicos e monofônicos, conforme variem as estratégias discursivas empregadas. Nos textos polifônicos, os diálogos entre os discursos mostram-se, deixam-se ver ou entrever, nos textos monofônicos eles se ocultam sob a aparência de um discurso único, de uma única voz. Monofonia e polifonia são, portanto, efeitos de sentido, decorrentes de procedimentos discursivos, de discursos por definição e constituição dialógicos. (BARROS, 1997, p. 34).

Para Barros, diferentemente do dialogismo "de todo discurso", a polifonia aconteceria quando o "dialogismo se deixa ver", 7 quando são "percebidas muitas vozes". Entretanto a polifonia não é uma questão de "explicitude" nem de "quantidade" das vozes convocadas a dialogar. $\mathrm{Na}$ polifonia, as vozes podem ser citadas de modo explícito ou serem insinuadas, pode haver muitas vozes ou uma mesma voz-ideia pode transitar por inúmeras conjunturas enunciativas. Mais importante para

\footnotetext{
${ }^{7}$ Essa definição da autora acerca da polifonia em muito lembra a concepção de intertextualidade exposta por Fiorin (2006), para quem o "termo intertextualidade fica reservado apenas para os casos em que a relação discursiva é materializada em texto", enquanto todas as demais relações dialógicas, manifestas ou não, são do campo da interdiscursividade.
} 
caracterizar a polifonia é que as vozes não permaneçam em uma única boca e que ninguém tenha a palavra mais forte, aquela capaz de encerrar o diálogo. No romance polifônico, Dostoiévski conseguiu isso ao conceber um narrador o mais próximo possível das personagens, além de criar toda uma arquitetônica romanesca em prol de fazer o herói se revelar, expor ao mundo, ao outro e a si mesmo as vozes que habitam sua autoconsciência.

\section{(iii) Distinguem-se polifonia de dialogismo, entendendo que a po- lifonia só se faz presente na prosa romanesca ou apenas na prosa romanesca dostoievskiana}

Trata-se da visão mais radical, mas, ao mesmo tempo, da mais "segura" quanto à distinção entre polifonia e dialogismo. Exemplo dessa visão é a posição de Bezerra (2005, p. 191-192):

O dialogismo e a polifonia estão vinculadas à natureza ampla e multifacetada do universo romanesco, ao seu povoamento por um grande número de personagens, à capacidade do romancista para recriar a riqueza dos seres e caracteres humanos traduzida na multiplicidade de vozes da vida social, cultural e ideológica representada.

Nesse caso, assume-se que a polifonia seja exclusiva da prosa romanesca ou ainda, de forma mais radical, específica a certos romances dostoievskianos. ${ }^{8}$ É uma posição segura, pois a leitura de Problemas da poética de Dostoiévski dá a entender que, de fato, a polifonia aparece apenas em certos romances de Dostoiévski. Como bem lembra Tezza (2003, p. 221-222, grifos do autor): "a categoria essencial do que ele [Bakhtin] chamou romance polifônico [...] a rigor, apenas o romancista russo [Dostoiévski] realizou em sua plenitude (pelo menos na justa dimensão bakhtiniana [...])".

Embora essa seja uma posição altamente confiável e, de fato, embasada nas proposições de Bakhtin, considerar que a polifonia é exclusiva de Dostoiévski pode levar a pouca produtividade do conceito.

Conforme indica Schnaiderman (1997, p. 20), "por mais relevância que tenham os trabalhos de teoria literária baseados em

${ }^{8}$ Bezerra (2005), vale lembrar, considera que também se pode falar de polifonia, por exemplo, no romance Esaú e Jacó (1904) de Machado de Assis. 
Bakhtin, e por mais que eles ainda nos possam dar, o que ele deixou delineado para a exploração de outros campos parece particularmente rico em sugestões".

Além disso, faltam pesquisas que possam comprovar que a prosa romanesca se diferencie, em termos de polifonia e de dialogismo, de outros gêneros. Somente com base em tais pesquisas seria ou não possível dizer se e como a polifonia e o dialogismo se apresentam em gêneros diversos. Ou seja, seria necessário analisar outros gêneros (literários ou não) e outros contextos enunciativos para se afirmar categoricamente se a polifonia só pode desenvolver-se na prosa romanesca.

Pesquisas essas que precisarão se distanciar de certa concepção que ainda toma o texto literário como detentor de uma "aura" elevada, como um texto especial ou sui generis. Para se afirmar que os textos literários detêm características que lhes propiciam ser mais adequados para a realização da polifonia, é necessário que se examinem outros gêneros e contextos, o que talvez prove (ou não) que a polifonia é exclusiva de certos gêneros da esfera literária.

\section{Considerações finais}

Na discussão proposta, pontuou-se que a polifonia depende de uma série de fatores que devem ocorrer concomitantemente em uma obra para que esta possa ser classificada como polifônica: deve haver relações entre diálogo, microdiálogo e grande diálogo; é necessária a passagem de temas e ideias por muitas e diferentes vozes; o diálogo permanece inconcluso, nem autor nem personagens podem dar a palavra final - o que se liga a uma singular posição do autor / narrador "ao lado" das personagens.

Não se trata, contudo, de propor um roteiro, um modelo a partir do qual se possa buscar verificar se um texto é ou não polifônico. Essas são características apontadas, embora não sistematicamente, por Bakhtin quando fala do romance polifônico dostoievskiano.

Ao se olhar para as especificidades do romance polifônico elencadas anteriormente, pode-se dizer que as relações dialógicas integram a polifonia, mas não coincidem com ela. No romance polifônico, expressa-se um conjunto específico de relações dialógicas. Os vínculos entre microdiálogo, diálogo e grande diálogo se realizam por meio de relações dialógicas. A passagem de um tema por muitas e diferentes vozes se dá por meio de relações dialógicas. Também a estruturação das vozes 
de tal modo que autor não se sobreponha às personagens está ligada a uma maneira singular de compor as relações dialógicas. No romance polifônico, portanto, há um conjunto de relações dialógicas particulares e um modo específico de organizá-las.

Além disso, é preciso pontuar que as relações dialógicas estão em estrita conexão com o gênero discursivo em que se realizam e com a esfera da comunicação em que emergem e são veiculadas. Certas características como a nova posição do autor e a passagem por muitas e diferentes vozes possivelmente não se fazem possíveis, pelo menos não totalmente, em outros gêneros mais curtos, pois são procedimentos que demandam um espaço composicional mais extenso.

Assim, mesmo que a polifonia, em princípio, seja algo exclusivo de Dostoiévski, seria ainda necessário notar que o arranjo polifônico está em estrita ligação com o gênero romanesco. Talvez seja possível em outros gêneros, mas não em todos. Ou seja, a polifonia pode estar associada às inovações específicas de Dostoiévski, mas essas inovações são dependentes do gênero discursivo em que se realizam.

Permanece aberta a questão de saber se essa configuração de relações dialógicas pode ser encontrada em outros textos, em outros gêneros, em outros autores que não certas obras dostoievskianas apontadas por Bakhtin como exemplares do romance polifônico.

De todo modo, ainda sem essas (necessárias) pesquisas futuras, já se pode pontuar hoje que polifonia não se distingue do dialogismo porque na polifonia estariam presentes várias vozes, enquanto no dialogismo apenas poucas (possivelmente duas) vozes se relacionariam. Também não se diferencia dialogismo de polifonia porque a ocorrência desta estaria associada à presença de vozes conflitantes, de vozes polemicamente inter-orientadas, enquanto no dialogismo haveria talvez um diálogo mais amistoso, quiçá com alguma assimilação de uma voz pela outra. São outros os critérios a se pensar quando se fala em polifonia: a amplitude do diálogo; as relações entre microdiálogo, diálogo composicionalmente expresso e grande diálogo; a questão do diálogo inconcluso.

\section{Referências}

BAKHTIN, M. M. (1929/1963). Problemas da poética de Dostoiévski. Trad. Paulo Bezerra. 5. ed. (2. tiragem). Rio de Janeiro: Forense Universitária, 2011. 
. [1952-1953]. Os gêneros do discurso. In: Estética da criação verbal. Trad. Paulo Bezerra. 4. ed. São Paulo: Martins Fontes, 2003.

BARROS, D. L. P. (1997). Contribuições de Bakhtin às teorias do discurso. In: BRAIT, B. (Org.) Bakhtin, dialogismo e construção do sentido. 2. ed. ver. Campinas, SP: Editora da Unicamp, 2005. p. 25-36.

BEZERRA, P. Polifonia. In: BRAIT, B. (Org.). Bakhtin: conceitos-chave. 2. ed. São Paulo: Contexto, 2005. p. 191-200.

BIANCHI, F. O "Sonhador" de A senhoria, de Dostoiévski: um "homem supérfluo". 2006. 175 p. Tese (Doutorado em Teoria Literária e Literatura Comparada) - Faculdade de Filosofia, Letras e Ciências Humanas, Universidade de São Paulo, São Paulo, 2006.

BRASIL. Parâmetros curriculares nacionais: terceiro e quarto ciclos: língua portuguesa. Brasília, DF: MEC / SEF, 1998.

BRAIT, B. (1994). As vozes bakhtinianas e o diálogo inconcluso. In: BARROS, D. L. P.; FIORIN, J. L. (Org.). Dialogismo, polifonia, intertextualidade: em torno de Bakhtin. 2. ed. 2. reimpr. São Paulo: EDUSP, 2011.

DOSTOIÉVSKI, F. M. (1881). Os irmãos Karamázov. Tradução, prefácio e notas de Paulo Bezerra. 3. ed. São Paulo: Editora 34, 2008.

EMERSON, C. (1997). Os 100 primeiros anos de Mikhail Bakhtin. Tradução Pedro Jorgensen Jr. Rio de Janeiro: DIFEL, 2003.

FARACO, C. A. (2003). Linguagem e diálogo: as ideias linguísticas do círculo de Bakhtin. 2. ed. Curitiba: Criar Edições, 2006.

FIORIN, J. L. Interdiscursividade e intertextualidade. In: BRAIT, B. (Org.). Bakhtin: outros conceitos-chave. 1. ed. São Paulo: Contexto, 2006. p. 161-193.

KOCH, I. G. V. O texto e a construção do sentido. Campinas: Contexto, 1997.

MARCUZZO, P. Diálogo inconcluso: os conceitos de dialogismo e polifonia na obra de Mikhail Bakhtin. Cadernos do IL, Porto Alegre, n. 36, p. 2-10, junho de 2008. Disponível em: <http://www.seer.ufrgs.br/ cadernosdoil >. Acesso em: 2 ago. 2015. 
SCHNAIDERMAN, B. (1997). Bakhtin 40 graus (Uma experiência brasileira). In: BRAIT, B. (Org.) Bakhtin, dialogismo e construção do sentido. 2. ed. rev. Campinas: Editora da Unicamp, 2005.

TEZZA, C. Entre a prosa e a poesia: Bakhtin e o formalismo russo. Rio de Janeiro: Rocco, 2003. 